\title{
DESIGN AND DEVELOPMENT OF OXYGEN MONITORING WITH GALVANIC OXYGEN SENSOR BASED ON MICROCONTROLLER ARDUINO UNO
}

\author{
Budi Prijo Sembodo*, Nanang Henri Vidal \\ Department of Electrical Engineering \\ University of PGRI Adi Buana Surabaya \\ *Corresponding email address: budi@unipasby.ac.id
}

\begin{abstract}
The Oxygen Analyzer is a tool for measuring the oxygen content in a gas exhaust system. The Oxygen analyzer is used in various fields including the fields of industry and health. In the health sector, the Oxygen Analyzer is used to measure oxygen content in Continuous Positive Airway Pressure (CPAP), anesthetic machines, ventilator machines, or oxygen cylinders. In this study the researchers made an Oxygen Analyzer that can read oxygen levels $21 \%$ $100 \%$ with a reading range per digit. This study uses an oxygen sensor that serves to detect oxygen levels which is set with an Arduino Uno microcontroller. The testing is carried out directly on a ventilator as a comparison tool. The method of data analysis in this study uses descriptive analysis. In this study the tool created was able to detect the value of oxygen levels in the range of $21 \%$ $100 \%$ with an average error of $0.01 \%$.
\end{abstract}

Keywords: Arduino Uno, Continuous positive airway pressure, Oxygen analyzer, Oxygen sensor.

\section{INTRODUCTION}

Oxygen Analyzer is a measuring instrument for oxygen content in a gas exhaust system in the presentation unit. The Oxygen analyzer is used in various fields including the fields of industry and health. In the health sector, the Oxygen Analyzer is used to measure the oxygen content in Continuous Positive Airway Pressure (CPAP) machines, ventilator machines, anesthetic machines or oxygen cylinders [1].

The CPAP tool is generally often used for medical services in hospitals. However, in some CPAP devices it is still not equipped with monitoring oxygen levels, so that the oxygen level released by the CPAP device is not known for its suitability with its level settings. It can give the negative impact for the patient. In the opinion of Arthur C Guyton and John E Hall (2007), if the body lacks oxygen, cells in our body will die so that the body's metabolism unstable, but too much oxygen can affect the lungs. For that, when giving oxygen to patients, it is necessary to pay attention to the oxygen level needed [2].

The related study has been conducted in 2015 by Kholikul Akram, by making an Oxygen Analyzer using an ATMega8 microcontroller. But the reading range made is $21 \%-90 \%$, whereas in the regulation of the Minister of Health of the Republic of Indonesia Number 4 of 2016 concerning the use of medical gas and vacuum in health service facilities is the oxygen level in a hospital agency required in medical services that is $>99,5 \%$ of Liquid oxygen and $>$ $90 \%$ of oxygen concentrator. Besides that, the increase in reading range used is tens so that it cannot read the increase in oxygen levels per digit [3].

Based on these problems, the researchers need to make a tool "Monitoring Oxygen Analyzer" which can read oxygen levels $21 \%$ $100 \%$ with a range of readings per digit of oxygen levels released by the tool so that oxygen is given to patients according to the settings.

\section{RESEARCH METHODS}

In the making module process, the researcher makes the design per block before assembling it in a single unified system. Module testing is done in two stages of the process, namely, testing partially or per part and testing the whole system where the module is made will perform a direct reading process on the Continuous Positive Airway Pressure (CPAP) or ventilator in the hospital. In testing the whole 
system, also carried out data retrieval and make a comparison with the data on the CPAP tool or ventilator at a particular hospital agency. After getting the data, the data will then be analyzed at an error rate so that it can draw conclusions from the data [4].

In its operational activities, the variables used in making modules, both variables are controlled, bound, and free to have functions including:

1. Free Variables: Oxygen levels are changes in oxygen levels that will be given to patients which are then detected by an oxygen sensor to measure the value of the presentation. Where changes in oxygen levels given to patients will affect the patient's condition by referring to the value of oxygen saturation in the patient's blood ( $\mathrm{SpO} 2)$.

2. Bound Variables: The measurement results of the oxygen analyzer are monitoring changes in the value of oxygen levels given to patients which are then detected by an oxygen sensor and will display the values in the presentation unit according to the changes in oxygen levels given.

The methods used in data collection:

1. Observation method that is recording the data of measurement results and testing of tools to be taken, namely the voltage of the oxygen sensor which is converted into a percentage of oxygen content.

2. The documentation method is to do calculations with the ADC formula on the
Arduino Uno microcontroller to get the value of oxygen levels in units of percent. This value will change according to the oxygen level of the giving or setting [5].

\section{RESULTS AND DISCUSSION}

The graph above is measurement and testing data of tools made on ventilators at Siloam Hospital Surabaya. Based on the results of the above data, the author can analyze, discuss and show whether the oxygen analyzer module can work well and in accordance with the expected or not. From the results of the data on testing the oxygen sensor shows that the increase in voltage at the oxygen sensor output is directly proportional to the increase in oxygen levels given to the oxygen sensor itself, proving that the results of the practice are in accordance with the theory and datasheet in the literature review, where oxygen sensors can detect oxygen levels in a room that is at least $21 \%$ with an oxygen sensor voltage of $15.1 \mathrm{mV}$ and can detect oxygen levels at $100 \%$ with an oxygen sensor voltage of $71.9 \mathrm{mV}$.

The making and use of programs for data processors in this module works properly as expected, where the module can display the value of oxygen levels from a range of $21 \%$ to $100 \%$.

From the data above, where the data taken is by increasing the setting of $x 5$ it is found that for the average percentage error of the setting value of $21 \%$ up to $100 \%$ is $0.01 \%$. With an average percentage error of $0.01 \%$ it can be

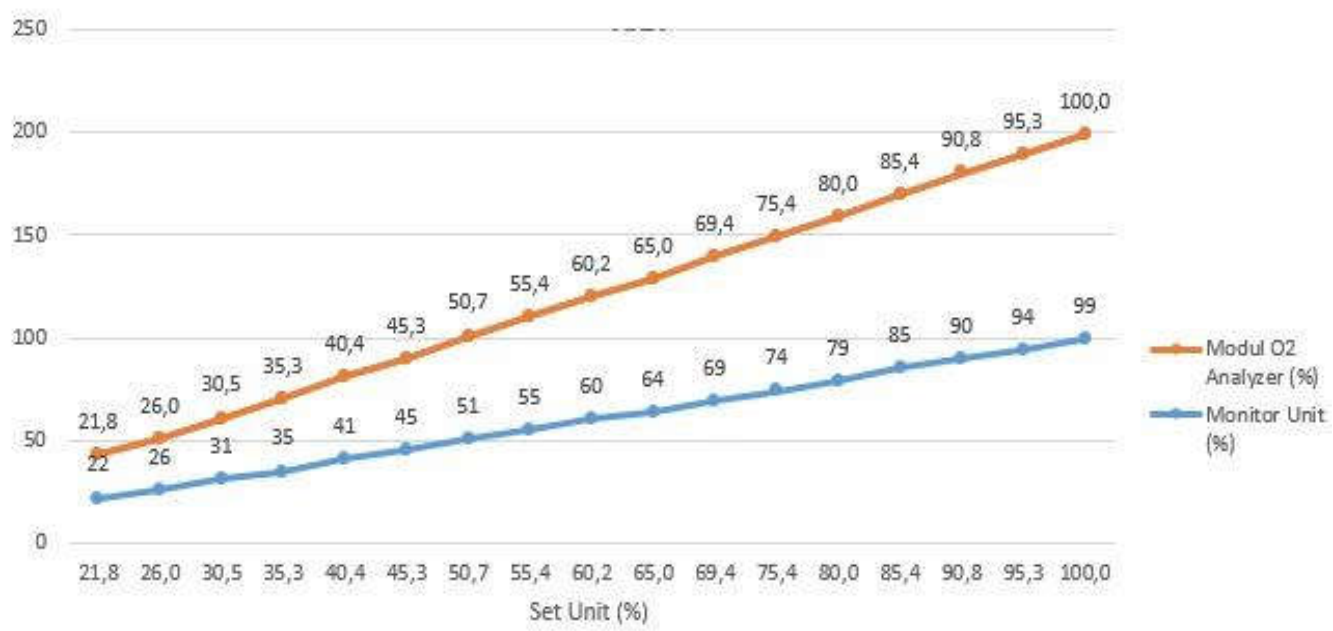

Figure 1. Comparison chart for measuring oxygen levels 
stated that the oxygen analyzer module works properly as expected.

When compared with the results of a study conducted in 2015 by Kholikul Akram, where the value of oxygen levels that can be read is the value from the range of $21 \%-90 \%$, while in this study the module can detect the value of oxygen levels from a range of $21 \%$ $100 \%$. In addition, the difference is that in the previous study the range of increase in reading was only per multiple of ten (x10), while in this study the range of reading increases could be per digit (x1)

\section{CONCLUSION}

From the results of testing the tools and analysis that have been done, it can be concluded that the testing of oxygen analyzer on a ventilator at Siloam hospital Surabaya is functioning properly and normally, which can detect oxygen levels at a minimum setting of $21 \%$ up to a maximum setting of $100 \%$ with resolution 1 digit reading with a presentation average of $0.01 \%$ error.

\section{ACKNOWLEDGMENT}

Appreciation of the author convey to all parties who have provided assistance in the form of guidance, direction, advice, support and convenience from the beginning to the end of the preparation of the Final Project. In this chance the author said thanks to Drs. H. Sugito, ST., MT as Dean and Ms. Atmiasri, ST., MT as Chair of the Electrical Engineering Study Program.

\section{REFERENCE}

[1] Mochamad Yusuf Santoso, "Sistem Sensor Oksigen Mochamad Yusuf Santoso." [Online]. Available: https://id.scribd.com/document/8837438 6/Sistem-Sensor-Oksigen-MochamadYusuf-Santoso. [Accessed: 14-May2019].

[2] A. C. G. J. E. Hall, Buku Ajar Fisiologi Kedokteran. Jakarta: EGC, 1997.

[3] Kholikul Akram Rodianta; H. Bambang Guruh Irianto; Syaifudin, "OXYGEN ANALYZER," J. Tek. Elektromedik Politek. Kesehat. Surabaya, 2015.

[4] S. Notoatmodjo, Metodologi penelitian kesehatan. Jakarta: Rineka Cipta, 2012.

[5] M. F. Wicaksono, Mudah Belajar Mikrokontroler Arduino. Bandung: Penerbit Informatika, 2017. 